\title{
EVALUASI BAHASA TEKS EKSPLANASI MENGGUNAKAN APRAISAL SIKAP (STUDI KASUS PADA ESSAY MAHASISWA PROGRAM STUDI PENDIDIKAN BAHASA DAN SASTRA INDONESIA UNIVERSITAS HKBP NOMMENSEN)
}

\section{oleh: \\ Sarma Panggabean \\ Universitas HKBP Nommensen \\ Universitas HKBP Nommensen; Jalan Perintis Kemerdekaan No 4a Medan forensik1988@gmail.com}

\begin{abstract}
Abstrak-Penelitian ini bertujuan untuk mengevaluasi bahasa essay mahasiswa pada pola Apraisal Sikap baik itu Afek, Penilaian, dan Apresiasi mahasiswa program studi Pendidikan Bahasa dan Sastra Indonesia, FKIP Universitas HKBP Nommensen. Penelitian ini dilaksanakan di Prodi Pendidikan Bahasa dan Sastra Indonesia tahun pembelajaran 2019/2020. Subjek penelitian ini adalah mahasiswa Grup A sebanyak 40 orang. Pada analisis konkordansi terdapat total kelas kata sebanyak 215 tipe; 410 token; 0,52439024 tipe token; 10,61809316 tipe squrt token; 92,32599643 pada pengukuran Yule. Dari hasil analisis konkordansi tersebut ditemukan data essay bentuk Apraisal Sikap, Penilaian>Apresiasi> Afek. kata kunci: essay, apraisal, afek, penilaian, apresiasi, sistem konkordansi.
\end{abstract}

\section{A. PENDAHULUAN}

Kerangka Apraisal merupakan suatu teori bahasa evaluatif, dikembangkan dalam tradisi linguistik sistemik fungsional. Kerangka kerja Apraisal merupakan pendekatan yang menjajaki, memerikan dan menjelaskan bagaimana bahasa digunakan untuk mengevaluasi, menunjukkan sikap mental, menyusun persona tekstual dan mengelola sikap dan hubungan antarpribadi. Pendekatan Apraisal menjajaki bagaimana penutur dan penulis menyampaikan penilaian tentang orang pada umumnya, penulis/penutur lainnya, dan ucapanucapannya, objek material, peristiwa dan keadaan, sehingga membentuk aliansi dengan orang-orang yang sama-sama memiliki pandangan ini dan memasang jarak dengan orangorang yang berpandangan berbeda. Martin dan White (2005: 35) menguraikan kerangka Apraisal terdiri dari tiga subsistem yang beroperasi secara paralel. Sikap melihat bagaimana seseorang mengekpresikan keadaan. Pemosisian mempertimbangkan tentang posisi seseorang. Graduasi menyelidiki bagaimana penggunaan fungsi bahasa menguatkan atau melemahkan sikap dan keterlibatan/pemosisian.

Pentingnya pengevaluasian bahasa tulis pada TEKS EKSPLANASI mahasiswa dilandasi oleh banyaknya mahasiswa yang menulis essay belum 
mempertimbangkan sikap baik itu afek, penilaian, dan apresiasi antara dirinya sebagai penulis dengan fenomena yang dikaji. Hal ini tentunya tidak baik dalam penyampaian hasil penyelidikan fakta yang didapat, meskipun ide berupa gejala kebahasaan sudah diperoleh dan dipastikan memiliki kesenjangan, tetapi jika tidak diredaksikan ke dalam uraian yang terarah maka hasilnya tidak akan bermanfaat dengan baik secara teoretis maupun praktis.

Gejala ini menjadi sangat penting dikaji sebab jika tidak diatasi dengan secepatnya, maka mutu akademik mahasiswa yang pertama sekali dilihat dari kemampuan menulis karya ilmiah akan sangat rendah. Tentu efeknya tidak baik perkembangan akademik dan kemampuan bersaing dalam berkarya ilmiah akan rendah. Hal inilah yang mendasari penelitian ini, sehingga diharapkan mahasiswa mampu menulis essay dengan benar sehingga dapat dipublikasi baik di media massa (koran, majalah, tabloit) maupun dilanjutkan ke dalam kajian ilmiah lainnya (skripsi, jurnal).

\section{B. KAJIAN TEORI}

\section{Evaluasi Bahasa}

Kerangka

Apraisal

merupakan suatu teori bahasa evaluatif, dikembangkan dalam tradisi linguistik sistemik fungsional. Kerangka Apraisal memerikan taksonomi tipe-tipe bahasa yang digunakan untuk menghubungkan evaluasi dan posisi seseorang dengan penghargaan terhadap evaluasi dari orang lain (Read \& Carrol 2012). Kerangka untuk analisis opini dalam linguistik sistemik fungsional dikembangkan atas nama Apraisal dengan tiga sub-kategori yaitu sikap, pemosisian, dan graduasi (lihat Martin dan White 2005), dan ada juga analisis stansial berdasarkan korpus (lihat Biber dan Conrad 2009).

Pembahasan evaluasi atau bahasa evaluatif dalam penelitian ini dapat dikelompokkan ke dalam tiga teori atau pendekatan yang utama (Hunston dan Thompson 2000). Ketiga pendekatan evaluasi ini adalah teori evaluasi berbasis parameter (Bednarek 2007), teori Stansial (Biber dan Conrad 2009), dan teori Apraisal (Martin \& White 2005). Persamaan dasar dari ketiga teori ini adalah bahwa evaluasi, stansial, ataupun apraisal termasuk ke dalam fungsi interpersonal bahasa. Perbedaan ketiganya umumnya terletak pada bagaimanakah evaluasi atau bahasa evaluatif didefenisikan, unsur-unsur apa saja yang termasuk ke dalam evaluasi, dan bagaimana unsurunsur ini dikategorisasikan dan ditentukan indikatornya.

\section{Kerangka Apraisal}

Martin dan White (2005: 35)

menguraikan kerangka Apraisal terdiri dari tiga subsistem yang beroperasi secara paralel. SIKAP melihat bagaimana seseorang mengekpresikan keadaan. PEMOSISIAN mempertimbangkan tentang posisi seseorang. 
GRADUASI menyelidiki bagaimana penggunaan fungsi bahasa menguatkan atau melemahkan sikap dan keterbabitan/pemosisian yang dihubungkan oleh teks.

\section{Sikap}

Sikap melihat bagaimana seseorang mengekpresikan keadaan. Aspek ini terbagi atas tiga bagian yaitu Afek, Penilaian, dan Apresiasi. Tiga subbagian apraisal Sikap yaitu Afek, Penilaian dan Apresiasi memiliki turunan kajian yang bervariasi. Ketiga sub bagian ini menunjukkan bagaimanakah sikap penutur atau penulis dalam menyampaikan pesannya kepada para pendengar dan pembaca baik melalui media lisan maupun tulisan. Dari analisis ketiga subsistem akan ditemukan sikap sesungguhnya dari penutur dan penulis pesan.

\section{Afek dalam Subkategori Sikap}

Istilah Afek pada umumnya digunakan untuk membicarakan ungkapan emosi dan perasaan.Istilah afek ini lebih umum digunakan dalam pembahasan bahasa emotif. Afekberhubungan dengan sumber daya yang menunjukkan perasaan negatif atau positif: apakah kita merasa senang atau sedih, yakin atau cemas, tertarik atau bosan. Dari segi polaritasnya, Afek memiliki dua subkategori yaitu positif dan negatif. Selain itu, Afek juga dibagi lagi dari segi cara dan nilai.

\section{Penilaian dalam Subkategori Sikap}

Istilah Penilaian merupakan wilayah makna yang merujuk pada sikap kita terhadap orang lain dan bagaimana mereka berperilakukarakter mereka. Penilaian secara umum dapat dibagi dalam dua kategori yaitu yang berhubungan dengan penghargaan sosial dan yang berorientasi kepada sanksi sosial (Martin \& White 2005).

\section{Apresiasi dalam subkategori Sikap}

Istilah Apresiasi merupakan wilayah makna yang merujuk pada evaluasi kita terhadap benda atau sesuatu, khususnya benda-benda yang kita buat dan penampilanpenampilan yang kita lakukan, termasuk juga fenomena alam. Martin dan White (2005: 56) menyatakan bahwa istilah Apresiasi pada umumnya dapat dibagi ke dalam reaksi kita terhadap bendabenda (apakah benda-benda itu menarik perhatian kita, apakah benda-benda itu menyenangkan kita?), komposisi benda-benda tersebut (seimbang atau kompleks), dan nilai benda-benda tersebut (inovatif, otentik, terjadi tepat pada waktu yang tepat, dll)

\section{Teks Eksplanasi}

Kosasih

mengatakan, "Teks eksplanasi adalah teks yang menjelaskan proses tentang asal usul, proses atau perkembangan suatu fenomena, mungkin berupa peristiwa alam, sosial, ataupun budaya". Menurut Kementerian Pendidikan Kebudayaan 2014:1 menyatakan,"Teks eksplanasi berisi penjelasan tentang keadaan sesuatu sebagai akibat dari sesuatu yang lain yang telah terjadi sebelumnya dan 
menyebabkan sesuatu yang lain lagi akan terjadi kemudian”.

$$
\text { Berdasarkan beberapa }
$$

pendapat para ahli diatas, maka dapat disimpulkan bahwa teks eksplanasi adalah teks yang mempelajari proses terjadinya suatu fenomena alam, ilmu pengetahuan, serta kehidupan sosial dan budaya.

\section{METODE PENELITIAN}

Penelitian ini menggunakan metode kualitatif dengan pendekatan deskriptif analitis. Pendekatan ini menetapkan persyaratan bahwa suatu penelitian harus dilakukan atas dasar fakta yang ada. Dengan demikian, pendekatan deskriptif memiliki sifat dan karakteristik yang dianggap sesuai digunakan dalam penelitian ini. Oleh karena itu, setiap konteks wacana yang diperoleh dari korpus diperiksa secara teliti untuk menentukan bentuk yang secara semantik berhubungan dengan parameter evaluatif. Penelitian ini menggunakan data empiris yang diperoleh apa adanya dengan melakukan analisis formal dan fungsional dalam penafsiran dan penarikan simpulan penelitian.

Sumber data berasal dari essay ilmiah mahasiswa yang telah dituliskan oleh mahasiswa tahun ajar genap di semester empat yang berjumlah 40 orang. Bahasa tulis dalam essay kemudian dijadikan objek penelitian. Pemaparan data meliputi jumlah kosa kata atau tipe, jumlah kata seluruhnya atau token, frekuensi kemunculan kata dalam teks, variasi leksikal teks, kepadatan kata dalam teks essay dan jumlah kata apraisal sikap, pemosisian, dan graduasi. Dari data tersebutdianalisis korpus dengan menggunakan perangkat lunak program korkodansi Simple Corcordance Program(SCP).

Setiap data yang diperoleh diidentifikasi dan diberi pemarkah apakah teks-teks itu termasuk dalam kategori sikap; afek, penilaian, dan apresiasi, kemudian, setiap subsistem Apraisal diklasifikasikan berdasarkan ungkapannya apakah kata-kata atau ungkapan tersebut memiliki kategori dalam sub-sistem Apraisal.

Metode analisis yang digunakan dalam penelitian ini adalah metode konkordansi dan distribusi dengan menggunakan perangkat lunak program konkordansi Simple Concordance Program (SCP). Melalui program ini, setiap kata Apraisal diteliti dalam setiap frasa dan klausa secara sintagmatik dan paradigmatik. Selanjutnya, dengan parameter kategori Apraisal.

\section{HASIL DAN PEMBAHASAN}

\section{Apraisal Sikap dalam Essay}

Kerangka analisis bahasa evaluatif ini menggunakan Simple Concordance Program (SCP) dalam menganalisis leksis data essay. Kajian ini menggunakan 2 tahapan; (1) menggunakan SCP untuk mendata seluruh leksis yang bersumber dari teks essay dengan perhitungan data meliputi: profil leksis (frekuensi leksis, penomoran leksis, jumlah kosa kata, persentasi 
kosa akat, dan persentasi leksis), dan analisis data secara statistik. (2) Mengkaji leksis dominan dalam setiap komponen Apraisal. Berikut diuraikan lebih rinci.

\section{Analisis Konkordansi}

Program konkordansi dapat membaca teks tulis untuk menghasilkan daftar kata dalam segala bahasa. Sistem konkordansi ini mengkalkulasi daftar kata yang ditelusuri dalam korpus linguistik untuk memeroleh leksikon secara komputasi dalam jumlah besar. Program ini menyajikan daftar kata, profil kata, dan hasil perhitungan kata secara statistik dalam program SCP tersebut.

\subsection{Daftar Kata}

\begin{tabular}{|c|c|}
\hline 2 adalah & 1 adanya \\
\hline 1 akhir & 1 akhirnya \\
\hline 2 akses & 2 amanda \\
\hline 1 amerika & 4 anak \\
\hline 1 ancaman & 9 atau \\
\hline 2 bagi & 1 bagian \\
\hline 2 bahkan & 2 bahwa \\
\hline 1 baik & 1 barack \\
\hline 1 bebas & 1 bekerja \\
\hline 1 belanda & 1 benua \\
\hline 1 berakhir & 1 berarti \\
\hline 1 berawal & 1 berbahaya \\
\hline 1 berbelanja & 1 berdiri \\
\hline 1 berlebihan & 1 \\
\hline \multicolumn{2}{|l|}{ bersangkutan } \\
\hline 1 bersifat & 1 bertindak \\
\hline 1 biasa & 2 bisa \\
\hline 1 bukanlah & 3 bully \\
\hline 1 bunuh & 1 cepat \\
\hline 1 daerah & 8 dalam \\
\hline 5 dan & 3 dapat \\
\hline 5 dari & 6 dengan \\
\hline $12 \mathrm{di}$ & 2 digunakan \\
\hline 1 dimanapun & 1 dimedia \\
\hline 1 dini & 1 dipicu \\
\hline 1 diri & 1 disaat \\
\hline 1 disebut & 1 ditangkap \\
\hline 7 dunia & 1 efek \\
\hline 1 eksploitasi & 1 email \\
\hline 1 facebook & 1 hacker \\
\hline 3 hal & 1 hanya \\
\hline
\end{tabular}

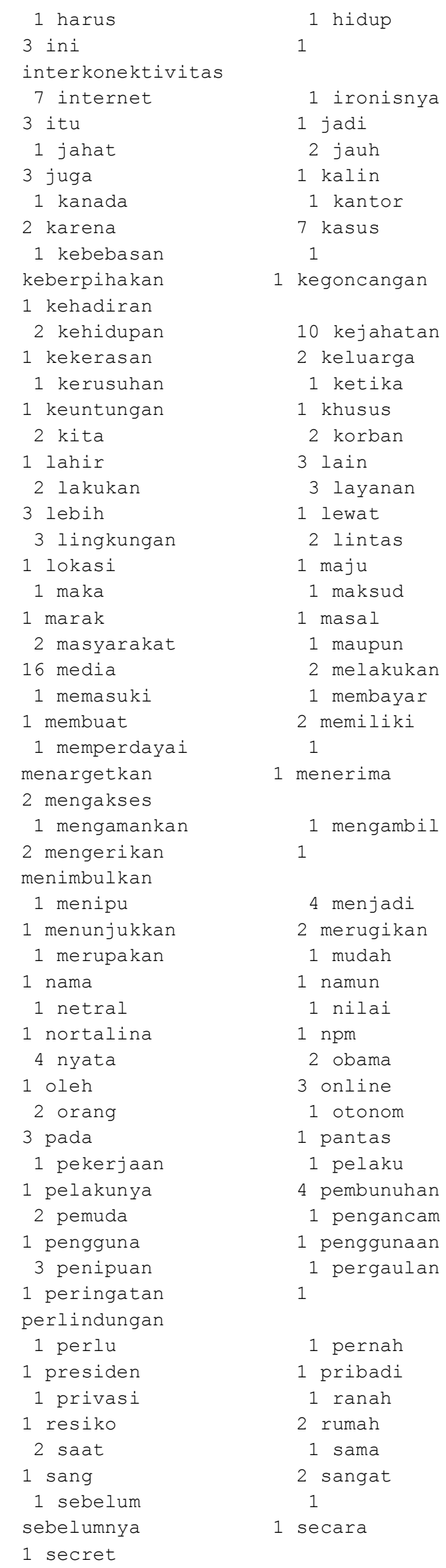


Bahasa Indonesia Prima, Vol 2, No. 2, 2020

e-ISSN: 2684-6780

$$
\begin{aligned}
& 1 \text { sejumlah } \\
& 1 \text { seksual } \\
& 2 \text { semakin } \\
& 1 \text { sendiri } \\
& 1 \text { sepasan } \\
& 1 \text { serikat } \\
& 1 \text { service } \\
& 1 \text { silaban } \\
& 19 \text { sosial } \\
& 2 \text { sudah } \\
& 1 \text { tagihan } \\
& 1 \text { teman } \\
& 1 \text { tentu } \\
& 2 \text { terhadap } \\
& 1 \text { terlibat } \\
& \text { termagnifasi } \\
& 1 \text { tersebut } \\
& 1 \text { terutama } \\
& 1 \text { tindakan } \\
& 1 \text { tood } \\
& 1 \text { transaksi } \\
& 5 \text { untuk } \\
& 1 \text { vika } \\
& 1 \text { website } \\
& 14 \text { yang } \\
&
\end{aligned}
$$

\begin{tabular}{|c|c|c|}
\hline Word & Number & Cumulative \\
\hline Cumulative & \multicolumn{2}{|c|}{ Percentage } \\
\hline \multicolumn{3}{|l|}{ Percentage } \\
\hline Frequency & \multicolumn{2}{|c|}{ of Words } \\
\hline Vocabulary & \multicolumn{2}{|c|}{ Word Count } \\
\hline Vocabulary & \multirow[t]{2}{*}{ Word } & Count \\
\hline 1 & & 148 \\
\hline 148 & \multirow[t]{2}{*}{148} & \multirow[t]{2}{*}{68,83721} \\
\hline 36,09756 & & \\
\hline 2 & \multicolumn{2}{|r|}{33} \\
\hline 181 & \multirow[t]{2}{*}{214} & \multirow[t]{2}{*}{84,18605} \\
\hline 52,19512 & & \\
\hline 3 & \multicolumn{2}{|r|}{14} \\
\hline 195 & 256 & 90,69767 \\
\hline \multicolumn{3}{|l|}{62,43902} \\
\hline 4 & \multicolumn{2}{|r|}{6} \\
\hline 201 & 280 & 93,48837 \\
\hline \multicolumn{3}{|l|}{68,29268} \\
\hline 5 & \multicolumn{2}{|r|}{3} \\
\hline 204 & 295 & 94,88372 \\
\hline \multicolumn{3}{|l|}{71,95122} \\
\hline 6 & \multicolumn{2}{|r|}{1} \\
\hline 205 & 301 & 95,34884 \\
\hline \multicolumn{3}{|l|}{73,41463} \\
\hline 7 & \multicolumn{2}{|r|}{3} \\
\hline 208 & 322 & 96,74419 \\
\hline \multicolumn{3}{|l|}{78,53659} \\
\hline 8 & \multicolumn{2}{|r|}{1} \\
\hline 209 & 330 & 97,2093 \\
\hline 80,4878 & & \\
\hline
\end{tabular}

\begin{tabular}{|c|c|c|}
\hline & & \\
\hline 210 & 339 & 97,67442 \\
\hline \multicolumn{3}{|c|}{82,68293} \\
\hline \multicolumn{2}{|c|}{10} & 1 \\
\hline 211 & 349 & 98,13953 \\
\hline \multicolumn{3}{|c|}{85,12195} \\
\hline \multicolumn{2}{|c|}{12} & 1 \\
\hline 212 & 361 & 98,60465 \\
\hline \multicolumn{3}{|c|}{88,04878} \\
\hline \multicolumn{2}{|c|}{14} & 1 \\
\hline 213 & 375 & 99,06977 \\
\hline \multicolumn{3}{|c|}{91,46341} \\
\hline \multicolumn{2}{|c|}{16} & 1 \\
\hline 214 & 391 & 99,53488 \\
\hline \multicolumn{3}{|c|}{95,36585} \\
\hline \multicolumn{2}{|c|}{19} & 1 \\
\hline 215 & 410 & 100 \\
\hline 100, & & \\
\hline
\end{tabular}

\subsection{Profil Kata}

Analisis berdasarkan daftar kata yang tersedia, diperoleh:

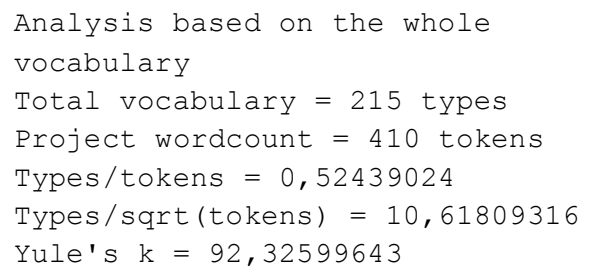

\section{Tabel 1}

Dominasi Apraisal Sikap dalam teks Essay

\begin{tabular}{|l|l|l|}
\hline \multirow{2}{*}{$\begin{array}{l}\text { Apraisal } \\
\text { Sikap }\end{array}$} & \multicolumn{2}{|c|}{ Essay } \\
\cline { 2 - 3 } & Jumlah & Persentase \\
\hline Afek & 18 & 12 \\
\hline Apresiasi & 40 & 26,6 \\
\hline Penilaian & 92 & 61,4 \\
\hline Total & 150 & 100 \\
\hline
\end{tabular}

Dari hasil analisis ditemukan bahwa data essay memiliki bentuk Apraisal Sikap, Penilaian > Apresiasi > Afek. Lebih jelasnya digambarkan dalam pie charts di bawah ini. 


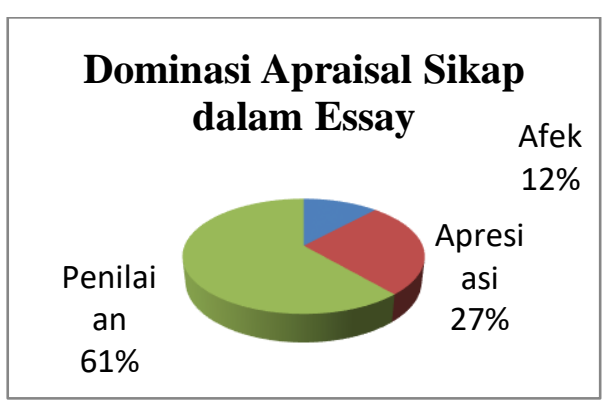

\section{E. PENUTUP}

\section{Simpulan}

Analisis Apraisal yang dilakukan dalam essay yang ditulis oleh para mahasiswa menunjukkan bahwa teks tersebut mahasiswa memberi gambaran sikap, pendirian, dan penilaian dalam teks dan konteks melalui bahasa evaluatif. Dalam kajian ini teks artikel mahasiswa dianalisis dalam tiga jenis apraisal Sikap yaitu Afek, Penilaian, dan Apresiasi. Pada analisis konkordansi terdapat total kelas kata sebanyak 215 tipe; 410 token; 0,52439024 tipe token; 10,61809316 tipe squrt token; 92,32599643 pada pengukuran Yule. Dari hasil analisis konkordansi tersebut ditemukan data essay bentuk Apraisal Sikap, Penilaian>Apresiasi> Afek.

\section{Saran}

Penelitian ini dilakukan untuk mengkaji Apraisal yang digunakan oleh mahasiswa dalam menghasilkan teks essay yang diharapkan layak untuk diterbitkan pada surat kabar. Adapun saran yang dapat diberikan dari hasil penelitian ini antara lain adalah:

a. Perlunya dilakukan penelitian lanjutan namun dengan menggunakan data bahasa tulis dari sumber yang lebih akurat misalkan data surat kabar berskala lokal maupun nasional. Di samping itu, data bahasa lisan juga merupakan penelitian Apraisal yang diasumsikan sebagai penelitian yang kaya akan temuan-temuan.

b. Penelitian pada ranah Apraisal perlu dikembangkan lagi dengan mengunakan korpus linguistik yang lebih besar lagi dalam hal ini linguistik forensik yang merupakan cabang linguistik baru sehingga dapat diperoleh gambaran yang lebih baik lagi tentang penggunaan bahasa evaluatif dalam teksteks yang bervariasi

\section{DAFTAR PUSTAKA}

Aikhenvald, Alexandra Y. 2004. Evidentiality. Oxford: Oxford University Press.

Bednarek, Monika. 2007. "Local Grammar and Register Variation: Explorations in Broadsheet and Tabloid Newspaper Discourse", ELR Journalhttp://ejournals.org.uk/ELR/a rticle/2007/1 (11 Januari 2016).

Besnier, N. 1990. 'Language and affect'. Annual Review of Anthropology 19: 59-88.

Biber, Douglas and Susan Conrad 2009. Register, Genre, and Style. Cambridge: Cambridge University Press.

Djuroto, Totok dan Bambang Suprijadi. 2003. Menulis Essay\& Karya Ilmiah. Bandung: Remaja Rosda Karya. 
Halliday, M.A.K. 1985/1994. Introduction to Functional Grammar. London: Arnold.

Hunston, Susan \& Geoff Thompson. 2000. Evaluation in Text: Authorial Stance and the Construction of Discourse. Oxford: Oxford University Press.

Johanson, Lars. and Bo Utas. Ed. 2000. Evidentials. Turkic, Iranian and Neighbouring Languages. Berlin/New York: Mouton de Gruyter.

Martin, J.R. \& White, P.R.R. 2005. Language of Evaluation: Appraisal in English. Basing stoke, UK: Palgrave.
Palmer, F.R. 1995. Modality and the English Modals. London: Longman.

Read, J dan Carroll, J. 2012. "Annotating expressions of appraisal in English". Language Resources \& Evaluation, Vol. 46, pp. 421 - 447.

Saragih, Amrin. 2006. Bahasa dalam Konteks Sosial: Pendekatan Linguistik SistemikFungsional terhadap Tata Bahasa dan Wacana. Medan: Pascasarjana Unimed.

Sinar, Tengku Sivana. 2003. Teori dan Analisis Wacana: Pendekatan Sistemik Fungsional. Medan: Pustaka Bangsa Press.

Sudaryanto. 1992. Metode Linguistik: Ke Arah Memahami Metode Linguistik. Yogyakarta: Gadjah Mada University Press. 